\title{
Leukoedema pada Perokok
}

\section{Priska T. Mambu, ${ }^{1}$ Pieter L. Suling, ${ }^{2}$ Aurelia S. R. Supit ${ }^{1}$}

\author{
${ }^{1}$ Program Studi Pendidikan Dokter Gigi Fakultas Kedokteran Universitas Sam Ratulangi \\ Manado \\ ${ }^{2}$ Bagian Ilmu Penyakit Kulit dan Kelamin Fakultas Kedokteran Universitas Sam Ratulangi \\ Manado \\ Email: priskatmambu@gmail.com
}

\begin{abstract}
Smokers can be found in almost all groups of people worldwide since cigarettes can be obtained easily anywhere and have been addicted by adult smokers. Leukoedema is one of the lesions in oral cavity that most often appears in smokers. This study was aimed to obtain the description of leukoedema cases among smokers. This was a literature review study. This study used previous studies or reports related to leukoedema in smokers. There were 13 literatures in this study consisting of 9 cross-sectional studies, 3 cohort studies, and 1 case control study. The results showed that leukoedema lesions were more common in smokers than in those who consumed tobacco. Leukoedema was closely related to the duration of smoking and the frequency of smoking in a day. Leukoedema was also more common in men than in women, and was often found bilaterally on the buccal mucosa. In conclusion, leucoedema was most common in cigarette smokers and was related to duration of smoking, frequency of smoking per day, and sex. It was often found bilaterally on the buccal mucosa.
\end{abstract}

Keywords: smokers, leukoedema

\begin{abstract}
Abstrak: Perokok ditemukan pada hampir semua kelompok masyarakat di dunia. Leukoedema merupakan salah satu lesi dalam rongga mulut yang paling sering muncul pada perokok. Penelitian ini bertujuan untuk mengetahui gambaran leukoedema pada perokok. Jenis penelitian ialah studi pustaka. Penelitian ini menggunakan topik terkait leukoedema pada perokok dari penelitian-penelitian sebelumnya. Pustaka yang diulas dan dipelajari dalam penelitian ini sebanyak 13 pustaka, terdiri dari 9 cross-sectional study, 3 cohort study, dan 1 case control study. Hasil penelitian ini memperlihatkan bahwa lesi leukoedema lebih sering ditemukan pada perokok dibandingkan yang tidak merokok meskipun mengonsumsi tembakau. Leukoedema erat hubungannya dengan lama kebiasaan merokok dan frekuensi merokok yang dilakukan dalam sehari. Leukoedema juga lebih sering ditemukan pada laki-laki dibandingkan perempuan, dan sering ditemukan pada mukosa bukal secara bilateral. Simpulan penelitian ini ialah leukoedema sering didapatkan pada perokok dan berhubungan erat dengan kebiasaan merokok, frekuensi merokok, jenis kelamin, dengan lokasi mukosa bukal bilateral.
\end{abstract}

Kata kunci: perokok, leukoedema

\section{PENDAHULUAN}

Dewasa ini perokok sudah ditemukan pada hampir semua kelompok masyarakat di dunia. Banyaknya jumlah perokok disebabkan antara lain karena rokok dapat diperoleh dengan mudah, di manapun juga, dan telah menjadi kebutuhan pokok bagi sebagian orang untuk mengonsumsi rokok. ${ }^{1}$ Banyak informasi yang beredar tentang penggunaan rokok yang dapat berdampak negatif bagi kesehatan individu, namun kebiasaan ini tidak dapat ditinggalkan dengan mudah. Kenyataannya jutaan remaja setiap tahun mulai merokok dan sekitar $85 \%$ remaja yang merokok akan tetap menjadi perokok pada usia dewasa. ${ }^{2}$ 
Secara global sebanyak 942 juta pria dan 175 juta wanita usia 15 tahun ke atas merupakan perokok, dan paparan terhadap perokok pasif sangat umum di banyak negara, terutama di Asia. ${ }^{3}$ Berdasarkan hasil Riset Kesehatan Dasar (RISKESDAS) tahun 2018, prevalensi perokok di Indonesia usia di atas 15 tahun mencapai angka 33,8\%. Dari jumlah tersebut laki-laki merupakan perokok terbanyak yaitu sebesar 62,9\% sedangkan perempuan hanya $4,8 \%$. Provinsi Sulawesi Utara berada pada urutan ke 10 dengan kategori perokok terbanyak yang mendekati angka $30 \%{ }^{4}$

Leukoedema merupakan salah satu lesi dalam rongga mulut yang paling sering muncul akibat merokok. Leukoedema biasanya berupa plak putih yang terletak pada mukosa bukal dan dianggap sebagai variasi normal. $^{5,6}$ Leukoedema pernah dianggap sebagai lesi premaligna tetapi pernyataan tersebut telah dihapus karena terbukti tidak memiliki potensi ganas. ${ }^{7}$ Penelitian yang dilakukan di Swedia oleh Axell dan Henricsson $^{8}$ melaporkan prevalensi lesi leukoedema sebanyak 48,9\%, sedangkan Anderson et $\mathrm{al}^{9}$ mendapatkan leukoedema sebanyak $67 \%$ sebagai lesi terbanyak dalam rongga mulut. Berbeda halnya dengan penemuan hasil studi di Iran oleh Sardari et al ${ }^{10}$ yang mendapatkan sebanyak $31,56 \%$ leukoedema dan hasil studi di Thailand oleh Reichart et $\mathrm{al}^{11}$ yang mendapatkan leukoedema sebanyak 3,78\%. Penelitian lainnya yang dilakukan oleh Anggraini ${ }^{12}$ di RSGMP FKG UI periode 15 Agustus - 15 Oktober 2008 melaporkan leukoedema sebesar 2,2\% pada pasien dengan kebiasaan merokok, sedangkan penelitian yang dilakukan oleh Enoch et $\mathrm{al}^{13}$ pada mahasiswa Papua yang berdomisili di Manado yang tergolong perokok aktif, melaporkan lesi leukoedema terjadi paling banyak di mukosa pipi sebanyak $91,1 \%$.

Leukoedema adalah salah satu varian normal jaringan lunak mulut yang harus diidentifikasi dengan tingkat keterampilan 4. Peraturan Konsil Kedokteran Indonesia (KKI) tentang standar kompetensi dokter gigi indonesia khususnya dalam bidang ilmu penyakit mulut meyatakan bahwa dokter gigi diharapkan mampu untuk mengidentifikasi varian normal jaringan lunak mulut sehingga dapat membedakan dengan lesi premaligna berdasarkan pemeriksaan intraoral yang dilakukan. Artinya seorang dokter gigi juga diharapkan mampu untuk melakukan diagnosis terhadap leukoedema secara mandiri. ${ }^{14}$

\section{METODE PENELITIAN}

Penelitian ini dilakukan selama bulan Mei-Juli 2020 di perpustakaan virtual. Jenis penelitian ialah kualitatif yang bersifat studi pustaka (literature review) dengan menggunakan buku-buku dan pustaka lainnya sebagai objek utama. Populasi dalam penelitian ini ialah seluruh jurnal dan artikel yang diperoleh dari Google scholar, PubMed, ScienceDirect, dan Perpustakaan Nasional Republik Indonesia dalam bentuk elektronik. Kriteria inklusi responden dalam pustaka ialah perokok, judul pustaka relevan dengan judul penelitian yakni leukoedema pada perokok, tahun publikasi pustaka 2010-2020, serta berbahasa Indonesia dan Inggris. Pustaka yang tidak tersedia full-text akan dieksklusi dan tidak terhitung sebagai sampel penelitian.

\section{HASIL PENELITIAN}

Data penelitian ini diperoleh dari google scholar, PubMed, ScienceDirect, dan Perpustakaan Nasional Republik Indonesia dalam bentuk elektronik. Penulis mendapatkan 13 pustaka yang telah melalui proses reduksi data sesuai dengan kriteria inklusi dan analisis yang terdiri dari 9 crosssectional study, 3 cohort study, dan 1 case control study; di antaranya 12 jurnal dari luar negeri dan 1 jurnal dari Indonesia. Tabel 1 memperlihatkan karakteristik 13 pustaka tersebut.

Tabel 2 menunjukkan bahwa prevalensi leukoedema pada responden yang memiliki kebiasaan merokok lebih tinggi dibanding responden dengan kebiasaan mengunyah tembakau maupun merokok dan mengunyah tembakau yakni 9 pustaka. Responden pada 1 pustaka lainnya Feng, et al ${ }^{15}$ tidak memperlihatkan leukoedema dengan kebiasaan apapun. 
Tabel 1. Karakteristik pustaka

\begin{tabular}{|c|c|c|c|c|c|c|c|c|}
\hline No & Penulis & $\begin{array}{c}\text { Lokasi } \\
\text { penelitian }\end{array}$ & $\begin{array}{l}\text { Jumlah } \\
\text { sampel }\end{array}$ & $\begin{array}{l}\text { Jumlah } \\
\text { populasi }\end{array}$ & $\begin{array}{c}\text { Jenis } \\
\text { penelitian } \\
\end{array}$ & Tahun & $\begin{array}{c}\text { Jenis } \\
\text { kelamin }\end{array}$ & $\begin{array}{c}\text { Usia } \\
\text { sampel }\end{array}$ \\
\hline 1 & $\begin{array}{l}\text { Anbalagan } \\
\text { et } \mathrm{al}^{16}\end{array}$ & $\begin{array}{l}\text { Tamilnadu, } \\
\text { India }\end{array}$ & 2.835 & 69.353 & $\begin{array}{l}\text { cross-sectional } \\
\text { observational } \\
\text { study }\end{array}$ & 2018 & $\begin{array}{l}\text { L: } 2.735 \\
\text { P: } 262\end{array}$ & $\begin{array}{l}20-60 \\
\text { tahun }\end{array}$ \\
\hline 2 & $\begin{array}{l}\text { Aishwarya et } \\
\mathrm{al}^{17}\end{array}$ & $\begin{array}{l}\text { Hyderabad, } \\
\text { India }\end{array}$ & 280 & 280 & $\begin{array}{c}\text { cross-sectional } \\
\text { study }\end{array}$ & 2017 & $\begin{array}{l}\text { L: } 272 \\
\text { P: } 8\end{array}$ & $\begin{array}{l}20-65 \\
\text { tahun }\end{array}$ \\
\hline 3 & $\begin{array}{l}\text { Amtha, } \\
\text { Kurniadi }^{18}\end{array}$ & $\begin{array}{l}\text { Jakarta, } \\
\text { Indonesia }\end{array}$ & 18 & 18 & $\begin{array}{l}\text { cross-sectional } \\
\text { observational } \\
\text { study }\end{array}$ & 2016 & $\begin{array}{l}\text { L: } 17 \\
\text { P: } 1\end{array}$ & $\begin{array}{l}15-55 \\
\text { tahun }\end{array}$ \\
\hline 4 & Joshi, Tailor $^{19}$ & India & 4.795 & 60.018 & $\begin{array}{l}\text { cross-sectional } \\
\text { study }\end{array}$ & 2016 & $\begin{array}{l}\text { L: } 4.176 \\
\text { P: } 619\end{array}$ & $\begin{array}{l}15-90 \\
\text { tahun }\end{array}$ \\
\hline 5 & Behura et $\mathrm{al}^{20}$ & $\begin{array}{l}\text { Chennai, } \\
\text { India }\end{array}$ & 300 & 450 & $\begin{array}{l}\text { case control } \\
\text { study }\end{array}$ & 2015 & $\begin{array}{l}\text { L: } 252 \\
\text { P: } 48\end{array}$ & $\begin{array}{l}15-75 \\
\text { tahun }\end{array}$ \\
\hline 6 & Aljabab et $\mathrm{al}^{21}$ & Arab & 536 & 536 & cohort study & 2015 & $\begin{array}{l}\text { L: } 536 \\
\text { P: } 0\end{array}$ & $\begin{array}{l}18-65 \\
\text { tahun }\end{array}$ \\
\hline 7 & Enoch $^{13}$ & $\begin{array}{l}\text { Manado, } \\
\text { Indonesia }\end{array}$ & 45 & 45 & cross-sectional & 2015 & $\begin{array}{c}\text { L: } 43 \\
\text { P: } 2\end{array}$ & $\begin{array}{l}15-30 \\
\text { tahun }\end{array}$ \\
\hline 8 & Feng et $\mathrm{al}^{15}$ & China & 11.054 & 11.054 & $\begin{array}{c}\text { cross-sectional } \\
\text { study }\end{array}$ & 2014 & $\begin{array}{l}\text { L: } 5.140 \\
\text { P: } 5.914\end{array}$ & $\begin{array}{l}1-96 \\
\text { tahun }\end{array}$ \\
\hline 9 & Ali et $\mathrm{al}^{22}$ & China & 530 & 530 & $\begin{array}{c}\text { cross-sectional } \\
\text { study }\end{array}$ & 2013 & $\begin{array}{l}\text { L: } 292 \\
\text { P: } 5.914\end{array}$ & $\begin{array}{l}15-45 \\
\text { tahun }\end{array}$ \\
\hline 10 & Patil et $\mathrm{al}^{23}$ & India & 2.400 & 2.400 & $\begin{array}{l}\text { cross-sectional } \\
\text { study }\end{array}$ & 2013 & $\begin{array}{l}\text { L: } 2.018 \\
\text { P: } 382\end{array}$ & $\begin{array}{l}15-75 \\
\text { tahun }\end{array}$ \\
\hline 11 & Sujatha et $\mathrm{al}^{24}$ & $\begin{array}{c}\text { Bangalore, } \\
\text { India }\end{array}$ & 1.028 & 1.028 & cohort study & 2012 & $\begin{array}{l}\text { L: } 904 \\
\text { P: } 124\end{array}$ & $\begin{array}{l}14-80 \\
\text { tahun }\end{array}$ \\
\hline 12 & $\begin{array}{l}\text { Chandra, } \\
\text { Govindraju }^{25}\end{array}$ & $\begin{array}{l}\text { Bangalore, } \\
\text { India }\end{array}$ & 361 & 1.525 & $\begin{array}{l}\text { cross-sectional } \\
\text { study }\end{array}$ & 2012 & $\begin{array}{c}\text { L: } 316 \\
\text { P: } 45\end{array}$ & $\begin{array}{c}5-80 \\
\text { tahun }\end{array}$ \\
\hline 13 & Morger et $\mathrm{al}^{26}$ & Swiss & 615 & 615 & cohort study & 2010 & $\begin{array}{l}\text { L: } 615 \\
\text { P: } 0\end{array}$ & $\begin{array}{l}18-24 \\
\text { tahun }\end{array}$ \\
\hline
\end{tabular}

Tabel 2. Gambaran leukoedema pada perokok berdasarkan kebiasaan merokok

\begin{tabular}{|c|c|c|c|c|c|}
\hline No & Penulis & Lokasi penelitian & Merokok & $\begin{array}{c}\text { Menguyah } \\
\text { tembakau }\end{array}$ & $\begin{array}{c}\text { Merokok dan } \\
\text { mengunyah tembakau }\end{array}$ \\
\hline 1 & Anbalagan et al ${ }^{16}$ & Tamilnadu, India & $11(0,7 \%)$ & 0 & 0 \\
\hline 2 & Aishwarya et al ${ }^{17}$ & Hyderabad, India & $6(12 \%)$ & 0 & $5(12,5 \%)$ \\
\hline 3 & Amtha, Kurniadi ${ }^{18}$ & Jakarta, Indonesia & $15(83,3 \%)$ & - & - \\
\hline 4 & Joshi, Tailor ${ }^{19}$ & Gujarat India & $114(6,5 \%)$ & $227(12,5 \%)$ & $18(14,4 \%)$ \\
\hline 5 & Behura et $\mathrm{al}^{20}$ & Chennai, India & $4(7,27 \%)$ & 0 & $2(5 \%)$ \\
\hline 6 & Aljabab et $\mathrm{al}^{21}$ & Arab & $86(16,04 \%)$ & $59(11 \%)$ & - \\
\hline 7 & Enoch $^{13}$ & Manado & $41(91,1 \%)$ & - & - \\
\hline 8 & Feng et a ${ }^{15}$ & China & 0 & - & - \\
\hline 9 & Ali et $\mathrm{al}^{22}$ & Kuwait, Arab & $17(3,2 \%)$ & - & - \\
\hline 10 & Patil et $\mathrm{al}^{23}$ & India & $3(0,25 \%)$ & 0 & $6(0,5 \%)$ \\
\hline 11 & Sujatha et $\mathrm{al}^{24}$ & Bangalore, India & $42(10,4 \%)$ & 0 & $28(12,4 \%)$ \\
\hline 12 & $\begin{array}{c}\text { Chandra, } \\
\text { Govindraju }\end{array}$ & India & $108(7,1 \%)$ & $6(0,4 \%)$ & $5(0,3 \%)$ \\
\hline 13 & Morger et $\mathrm{al}^{26}$ & Swiss & $4(0,85 \%)$ & - & - \\
\hline
\end{tabular}

Tabel 3 memperlihatkan bahwa seluruh pustaka yang menyajikan prevalensi leukoedema pada responden berdasarkan kategori perokok menyimpulkan bahwa leukoedema pada perokok sigaret lebih tinggi dibandingkan pada responden dengan kategori 
perokok shisha maupun kategori perokok sigaret dan shisha.

Tabel 4 memperlihatkan bahwa prevalensi tertinggi leukoedema terdapat pada respoden yang memiliki kebiasaan merokok 1-5 tahun yakni 20 orang $(44,4 \%)$, diikuti responden dengan kebiasaan merokok selama 5-10 tahun sebanyak 17 orang $(37,8 \%)$ dan responden dengan kebiasaan merokok $>10$ tahun sebanyak 4 orang $(8,9 \%)$.

Tabel 5 menunjukkan bahwa responden yang memiliki leukoedema dalam penelitian Enoch et al ${ }^{13}$ melakukan kebiasaan merokok sebanyak 1-10 kali (perokok ringan) dalam sehari sebanyak 19 orang $(42,2 \%)$ merokok sebanyak 11-20 kali (perokok sedang) dalam sehari sebanyak 15 orang $(33,3 \%)$ dan merokok sebanyak lebih dari 20 kali (perokok berat) dalam sehari sebanyak 7 orang $(15,6 \%)$.

Tabel 6 menunjukkan bahwa seluruh lesi leukoedema pada perokok dalam penelitian yang dilakukan oleh Enoch et $\mathrm{al}^{13}$ dan Ali et $\mathrm{al}^{22}$ berlokasi pada mukosa bukal.

Tabel 7 menunjukkan bahwa seluruh pustaka yang menyajikan lesi leukoedema pada perokok berdasarkan jenis kelamin responden yakni 7 pustaka menyatakan bahwa leukoedema memiliki prevalensi yang lebih besar pada laki-laki dibandingkan perempuan.

Tabel 3. Gambaran leukoedema pada perokok berdasarkan kategori perokok

\begin{tabular}{|c|c|c|c|c|c|}
\hline No & Penulis & Lokasi penelitian & $\begin{array}{c}\text { Perokok } \\
\text { sigaret }\end{array}$ & $\begin{array}{c}\text { Perokok } \\
\text { shisha }\end{array}$ & $\begin{array}{l}\text { Perokok siga- } \\
\text { ret dan shisha }\end{array}$ \\
\hline 1 & Anbalagan et $\mathrm{al}^{16}$ & Tamilnadu, India & $11(100 \%)$ & - & - \\
\hline 2 & Aishwarya et al ${ }^{17}$ & Hyderabad, India & $11(100 \%)$ & - & - \\
\hline 3 & Amtha, Kurniadi ${ }^{18}$ & Jakarta Indonesia & $9(90 \%)$ & $1(50 \%)$ & $5(83,3 \%)$ \\
\hline 4 & Joshi, Tailor ${ }^{19}$ & Gujarat India & $132(100 \%)$ & - & - \\
\hline 5 & Behura et $\mathrm{al}^{20}$ & Chennai India & $6(100 \%)$ & - & - \\
\hline 6 & Aljabab et $\mathrm{al}^{21}$ & Arab & Arab & - & - \\
\hline 7 & Enoch $^{13}$ & Manado & $41(100 \%)$ & - & - \\
\hline 8 & Ali et $\mathrm{al}^{22}$ & Kuwait, Arab & $17(100 \%)$ & - & - \\
\hline 9 & Patil et $\mathrm{al}^{23}$ & India & $9(100 \%)$ & - & - \\
\hline 10 & Sujatha et $\mathrm{al}^{24}$ & India & $70(100 \%)$ & - & - \\
\hline 11 & Chandra et $\mathrm{al}^{25}$ & India & $113(100 \%)$ & - & - \\
\hline 12 & Morger et $\mathrm{al}^{26}$ & Swiss & $4(100 \%)$ & - & - \\
\hline
\end{tabular}

Tabel 4. Gambaran leukoedema pada perokok berdasarkan lama merokok

\begin{tabular}{cccccc}
\hline No & Peneliti & Lokasi penelitian & $\mathbf{1 - 5}$ tahun & $\mathbf{5 - 1 0}$ tahun & $>$ 10 tahun \\
\hline 1 & Enoch $^{13}$ & Manado, Indonesia & $20(44,4 \%)$ & $17(37,8 \%)$ & $4(8,9 \%)$ \\
\hline
\end{tabular}

Tabel 5. Gambaran leukoedema pada perokok berdasarkan frekuensi merokok dalam 1 hari

\begin{tabular}{|c|c|c|c|c|c|}
\hline No & Penulis & Lokasi penelitian & 1-10 kali & 11-20 kali & $>20$ kali \\
\hline 1 & Enoch $^{13}$ & Manado, Indonesia & $19(42,2 \%)$ & $15(33,3 \%)$ & $7(15,6 \%)$ \\
\hline
\end{tabular}

Tabel 6. Gambaran leukoedema pada perokok berdasarkan lokasi lesi

\begin{tabular}{ccccccc}
\hline No & Penulis & Lokasi penelitian & $\begin{array}{c}\text { Mukosa } \\
\text { bukal }\end{array}$ & $\begin{array}{c}\text { Mukosa } \\
\text { labial }\end{array}$ & Palatum & $\begin{array}{c}\text { Dasar } \\
\text { mulut }\end{array}$ \\
\hline 1 & Enoch $^{13}$ & Manado, Indonesia & $41(100 \%)$ & 0 & 0 & 0 \\
2 & ${\text { Ali et } \mathrm{al}^{22}}^{22}$ & Kuwait, Arab & $17(100 \%)$ & 0 & 0 & 0 \\
\hline
\end{tabular}


Tabel 7. Gambaran leukoedema pada perokok berdasarkan jenis kelamin

\begin{tabular}{ccccc}
\hline No & Penulis & Lokasi penelitian & Laki-laki & Perempuan \\
\hline 1 & Anbalagan et al $^{16}$ & India & $11(100 \%)$ & 0 \\
2 & Amtha, Kurniadi $^{18}$ & Jakarta & $15(100 \%)$ & 0 \\
3 & Enoch $^{13}$ & Manado & $39(95,12 \%)$ & $2(4,88 \%)$ \\
4 & Patil et al $^{23}$ & India & $9(100 \%)$ & 0 \\
5 & Sujatha et al $^{24}$ & India & $70(100 \%)$ & 0 \\
6 & Chandra et al $^{25}$ & India & $113(100 \%)$ & 0 \\
7 & Morger et al $^{26}$ & Swiss & $4(100 \%)$ & - \\
\hline
\end{tabular}

\section{BAHASAN}

Hasil penelitian pada 13 pustaka yang telah diulas, menunjukkan bahwa leukoedema lebih sering ditemukan pada individu yang memiliki kebiasaan merokok dibandingkan dengan yang hanya memiliki kebiasaan mengunyah tembakau. Perbedaan yang sangat bermakna dari 13 pustaka tersebut dapat dilihat pada penelitian oleh Chandra dan Govindraju ${ }^{25}$ yang melaporkan kejadian leukoedema pada $7,1 \%$ perokok, $0,4 \%$ pada pengunyah tembakau, dan $0,3 \%$ pada perokok sekaligus pengunyah tembakau. Sementara itu, penelitian yang dilakukan oleh Aljabab et $\mathrm{al}^{21}$ memperoleh kejadian leukoedema pada $16,04 \%$ perokok dan $11 \%$ pengunyah tembakau. Hal ini dapat disebabkan karena selain zat-zat karsinogen yang terdapat dalam tembakau, panas yang dihasilkan dari pembakaran rokok dengan bahan dasar tembakau, dapat menambah aksi yang agresif pada mukosa rongga mulut, sehingga perokok lebih berisiko terkena leukoedema dibandingkan dengan yang hanya mengonsumsi tembakau dengan cara mengunyah tembakau. ${ }^{27,28}$

Seluruh pustaka dalam penelitian ini menunjukkan bahwa leukoedema lebih sering ditemukan pada perokok sigaret dibandingkan perokok yang mengonsumsi jenis rokok lain. Hanya 1 dari 13 pustaka yaitu penelitian oleh Amtha ${ }^{18}$ yang melaporkan bahwa pada responden selain perokok sigaret yaitu perokok shisha, kejadian leukoedema pada perokok ditemukan pada $90 \%$ perokok sigaret, $50 \%$ perokok shisha, dan 83,3\% pada perokok sigaret dan shisha. Ke 11 pustaka lainnya menunjukkan $100 \%$ leukoedema pada perokok yaitu perokok sigaret. Hal ini terjadi karena jenis rokok yang digunakan oleh responden pada pustaka hanya rokok sigaret, dan sangat jarang ditemukan pustaka yang meneliti mengenai leukoedema pada perokok dengan jenis rokok selain rokok sigaret.

Hasil penelitian ini menunjukkan bahwa rerata kebiasaan merokok yang dilakukan oleh responden dengan leukoedema pada penelitian Enoch et $\mathrm{al}^{13}$ yakni selama $1-5$ tahun $(44,4 \%)$, dengan rerata frekuensi merokok sebanyak 1-10 kali dalam sehari $(42,2 \%)$. Ke 11 pustaka lainnya tidak memberikan gambaran yang jelas mengenai kebiasaan merokok berdasarkan lama dan frekuensi merokok yang dilakukan oleh responden dengan leukoedema, namun penelitian yang dilakukan oleh Aljabab et $\mathrm{al}^{21}$ menyatakan bahwa leukoedema paling banyak ditemukan pada responden yang telah memiliki kebiasaan menggunakan tembakau, termasuk merokok, mengunyah tembakau, maupun kedua kebiasaan tersebut selama $>15$ tahun $(11,94 \%)$, dengan rerata frekuensi menggunakan tembakau sebanyak 1-5 kali dalam sehari (11\%).

Data yang diperoleh dalam penelitian ini menunjukkan bahwa leukoedema pada perokok paling banyak ditemukan di mukosa bukal kanan dan kiri secara bilateral sebesar $100 \%$. Hal ini sejalan dengan penelitian yang dilakukan oleh Martin dan Crump $^{29}$ pada 1000 anak dan remaja Negro yaitu semua responden yang memiliki leukoedema $(50,8 \%)$ berlokasi secara bilateral pada mukosa bukal. Hasil ini juga selaras dengan penelitian oleh Pindborg et $\mathrm{al}^{30}$ yang mendapatkan lokasi leukoedema paling banyak ditemukan pada mukosa 
bukal secara bilateral sebesar 94\%. Hal ini didukung oleh penelitian oleh Holland et $\mathrm{al}^{31}$ yang menyebutkan bahwa sel-sel mukosa bukal dapat melakukan metabolisme suatu zat karsinogenik spesifik pada tembakau rokok menjadi suatu produk yang reaktif, dibandingkan dengan lokasi yang lain dalam rongga mulut.

Hasil penelitian ini juga menunjukkan bahwa leukoedema pada perokok lebih sering ditemukan pada laki-laki dibandingkan perempuan. Perbedaan yang sangat bermakna didapatkan oleh Chandra dan Govindraju ${ }^{25}$ yang menyatakan prevalensi leukoedema pada perokok berjenis kelamin laki-laki sebanyak 113 orang $(100 \%)$ dan tidak ditemukan leukoedema pada perempuan yang melakukan kebiasaan merokok. Hal ini juga sejalan dengan penelitian yang dilakukan oleh Sujatha et $\mathrm{al}^{24}$ yang menyatakan bahwa leukoedema pada perokok hanya ditemukan pada laki-laki yaitu sebanyak 70 orang $(100 \%)$. Hal ini kemungkinan dapat terjadi karena kebiasaan merokok lebih sering dilakukan oleh laki-laki dibandingkan perempuan.,

\section{SIMPULAN}

Lesi leukoedema lebih banyak ditemukan pada perokok dibandingkan pengunyah tembakau. Mayoritas lesi leukoedema ditemukan pada perokok sigaret, telah memiliki kebiasaan merokok selama 1-5 tahun, kebiasaan merokok sebanyak 1-10 kali dalam sehari, lokasi pada mukosa bukal secara bilateral, dan jenis kelamin laki-laki.

\section{Konflik Kepentingan}

Penulis menyatakan tidak terdapat konflik kepentingan dalam studi ini.

\section{DAFTAR PUSTAKA}

1. Jaya M. Pembunuh Berbahaya Itu Bernama Rokok. Yogyakarta: Riz'ma, 2009.

2. Djauzi S. Raih Kembali Kesehatan. Jakarta: Kompas, 2009.

3. Drope J. The Tobacco Atlas (6th ed). Georgia: The American Cancer Society, 2018.

4. Badan Penelitian dan Pengembangan Kesehatan. Hasil utama Riskesdas 2018. Jakarta: Kemenkes RI, 2018; p. 123-5.
5. Warnakulasuriya S, Dietrich T, Bornstein M, Peidró E, Preshaw P, Walter C, et al. Oral health risks of tobacco use and effects of cessation. Int Dent J. 2010: 60(1):7-30.

6. Shafer GW, Hine MK, Levy BM. Benign and malignant tumors of the oral cavity. In: Rajendran R, Shivapatha SB, editors. Shafer's Textbook of Oral Pathology (7 th ed). India: Elsevier, 2012; p. 92-3.

7. Carnelio S, Rodrigues GS, Shenoy R, Fernandes D. A brief review of common oral premalignant lesions with emphasis on their management and cancer prevention. Indian J Surg. 2011; 73(4):256-61.

8. Axell T, Henricsson V. Leukoedema - an epidemiologic study with special reference to the influence of tobacco habits. Community dent oral epidemiol. 1981; 9(3):142-6.

9. Anderson G, Vala EK, Curvall M. The influence of cigarette consumption and smoking machine yield of tar and nicotine uptake and oral mucosal lesions in smokers. J Oral Pathol Med. 1997;26(3):117-23

10. Sardari F, Ghalaiani P, Basij F. Determining relative frequency of leukoedema and evaluation of its risk factors in patients referring to the department of oral medicine in Isfahan Faculty of Dentistry. Journal of Isfahan Dental School. 2011;7(1):24-30.

11. Reichart PA, Mohr U, Srisuwan S, Geerlings $\mathrm{H}$, Theetranont C, Kangwanpong $\mathrm{T}$. Precancerous and other oral mucosal lesions related to chewing, smoking and drinking habits in Thailand. Community Dent Oral Epidemiol. 1987;15:15260.

12. Anggraini CM. Prevalensi dan distribusi variasi anatomis normal pada pasien Rumah Sakit Gigi Dan Mulut Fakultas Kedokteran Gigi Indonesia berdasarkan lokasi, usia, dan jenis kelamin. [cited 2020 May 12]. Available from: https:// adoc.tips/queue/fakultas-kedokterangigi-universitas-indonesia-bab-5pembaha.html.

13. Enoch EY, Suling PL, Supit ASR. Gambaran kebiasaan merokok dan leukoedema pada mahasiswa Papua di Manado. eGiGi. 2015;3(1):3-6.

14. Peraturan Konsil Kedokteran Indonesia 
Nomor 40 Tahun 2015 tentang Standar Kompetensi Dokter Gigi Indonesia. Jakarta: KKI, 2015; p. 80-1.

15. Anbalagan P. Prevalence of oral lesions associated with tobacco use among patients visiting Institute of Dental Scienece and Research Truchengode - a cross sectional observational study [Dissertation]. 2018; p. 31-53. [cited 2020 June 15]. Available from: http:// repository-tnmgrmu.ac.in/10015/

16. Aishwarya KM, Reddy MP, Kulkarni S, Doshi D, Reddy BS, Satyanarayana D. Effect of frequency and duration of tobacco use on oral mucosal lesions - a crosssectional study among tobacco users in Hyderabad, India. Asian Pac J Cancer Prev. 2017;18(8):2233-38.

17. Amtha R, Kurniadi A. An overview of oral mucosa condition of shisha smoker. Journal of Dentomaxilofacial Science. 2016;1(2):80-3.

18. Joshi M, Tailor M. Prevalence of most commonly reported tobacco-associated lesions in central Gujarat: A hospitalbased cross-sectional study. Indian Journal of Dental Research. 2016; 27(4):405-9.

19. Behura SS, Masthan MK, Narayanasamy AB. Evaluation of oral changes among tobacco users of Aljouf Province, Saudi Arabia. J Clin Diag Res. 2015; 9(7):1722.

20. Aljabab MA, Aljabab AA, Patil SR. Evaluation of oral changes among tobacco users of Aljouf Province, Saudi Arabia. J Clin Diag Res. 2015;9(5):5861.

21. Feng J, Zhou Z, Shen X, Wang YF, Shi L, Wang YJ, et al. Prevalence and distribution of oral mucosal lesions: a cross-sectional study in Shanghai, China. J Oral Pathol Med. 2015;44(7): 490-4.

22. Ali M, Joseph B, Sundaran D. Prevalence of oral mucosal lesions in patients of the Kuwait University Dental Center. Saudi Dent J. 2013;25(3):111-8.
23. Patil PB, Bathi R, Chaudhari S. Prevalence of oral mucosal lesions in dental patients with tobacco smoking, chewing, and mixed habits: A cross-sectional study in South India. J Fam Community Med. 2013;20(2):130-5.

24. Sujatha D, Hebbar PB, Pai A. Prevalence and correlation of oral lesions among tobacco smokers, tobacco chewers, areca nut and alcohol users. Asian Pac J Cancer Prev. 2012;13(4):1633-7.

25. Chandra P, Govindraju P. Prevalence of oral mucosal lesions among tobacco users. Oral Health Prev Dent. 2012;10(2):14953.

26. Morger R, Ramseier CA, Rees TD, Burgin WB, Bornstein MM. Oral mucosal findings related to tobacco use and alcohol consumption: a study on Swiss army recruits involving self-reported and clinical data. Oral Health Prev Dent. 2010;8(2):143-51.

27. Palaskar, Jindal C. Evaluation of micronuclei using Papanicolaou and May Grunwald Giemsa stain in individuals with different tobacco habits - a comparative study. J Clin Diag Res. 2010; 4:3607-13

28. De Marini DM. Genotoxicity of tobacco smoke and tobacco smoke condensate: a review. Mutat Res. 2004;567(2-3): 447-74.

29. Martin JL, Crump EP. Leukoedema in buccal mucosa in Negro children and youth. Oral Surgery Oral Medicine and Oral Pathology. 1972;34(1):49-58.

30. Pindborg JJ, Barmes D, Roed OB. Epidemiology and histology of oral leukoplakia and leukoedema among Papuans and New Guineans. Cancer. 1968;22(2):379-84.

31. Holland N, Claudia B, Micheline K-V, Bonassi S, Zeiger E, Knasmueller S, et al. The micronucleus assay in human buccal cells as a tool for biomonitoring DNA damage: the HUMN project perspective on current status and knowledge gaps. Mutat Res. 2008;659(12):93-108. 